\title{
Occurrence of anti Sarcocystis spp., anti Toxoplasma gondii, and anti Neospora spp. antibodies in equines from western Santa Catarina, Brazil
}

\author{
Ocorrência de anticorpos anti Sarcocytis spp., \\ anti Toxoplasma gondii e anti Neospora spp. em \\ equinos da região Oeste de Santa Catarina
}

\author{
Alana Birck Ribeiro1; Maysa Bigolin Chitolina2; Andressa Carminatti3; \\ Fagner D'ambroso Fernandes ${ }^{4}$; Patricia Bräunig ${ }^{5}$; Fernanda Silveira Flôres Vogel ${ }^{6}$; \\ Alan Miranda Prestes ${ }^{7}$; Silvana Giacomini Collet ${ }^{7}$; Giovana Camillo ${ }^{7 *}$
}

\section{Highlights}

Equines from western Santa Catarina have Antibodies against Apicomplexa protozoa.

Equines seropositive to the three agents was observed in different environments.

A high percentage of positive equines and in contact with definitive hosts.

\begin{abstract}
Equine raising is generally articulated as a secondary activity on farms, where animals are used for leisure or work. Thus, it is important to consider the health of these animals, seeking to understand which are the main agents that circulate in a given farm or region. In this sense, this study aimed to evaluate the presence of IgG anti-Sarcocystis spp., anti-Toxoplasma gondii, and anti-Neospora spp. antibodies in equines in western Santa Catarina, Brazil. A total of 100 serum samples from horses from 10 farms, located in the municipalities

1 Student of the Undergraduate Course in Veterinary Medicine, University of the West of Santa Catarina, UNOESC, Xanxerê, SC, Brasil. E-mail: alanaaribeiro1002@gmail.com

2 Student of the Undergraduate Course in Veterinary Medicine, UNOESC, Xanxerê, SC, Brasil. E-mail: maysaalsk@gmail. com

${ }^{3}$ Student, Master's Program in Health and Animal Production, UNOESC, Xanxerê, SC, Brazil. E-mail: andressa.carminatti@ unoesc.edu.br

${ }^{4}$ Student, Master's Program in Veterinary Medicine, Laboratory of Parasitic Diseases, Department of Veterinary Preventive Medicine, Federal University of Santa Maria, UFSM, Santa Maria, RS, Brasil. E-mail: fagnermedvet@ gmail.com

${ }^{5}$ Pharmaceutical and Researcher, Laboratory of Parasitic Diseases, Department of Veterinary Preventive Medicine, UFSM, Santa Maria, RS, Brasil. E-mail: pbraunig@gmail.com

6 Teacher and Researcher, Program in Veterinary Medicine, Laboratory of Parasitic Diseases, Department of Veterinary Preventive Medicine, UFSM, Santa Maria, RS, Brasil. E-mail: fefevogel@gmail.com

7 Teacher and Researcher, Master's Program in Health and Animal Production, UNOESC, Xanxerê, SC, Brazil. E-mail: alan. prestes@unoesc.edu.br; silvana.collet@unoesc.edu.br; giovana.camillo@unoesc.edu.br

* Author for correspondence
\end{abstract}

Received: July 30, 2020 - Approved: Feb. 19, 2021 
of Faxinal dos Guedes, Xaxim, and Xanxerê were analyzed from June to December 2019. The samples were evaluated by indirect immunofluorescence reaction (IIFR) to detect antibodies of IgG class against the three agents. The results showed that the equines in the region are seropositive against the three studied agents, $11 \%$ of which for Sarcocystis spp. $21 \%$ for T. gondii, and $20 \%$ for Neospora spp. The analysis of the presence of these protozoa in different environments showed that both stabled and extensively raised horses presented signs of contact with the studied agents. Animals that live only in stables had a higher occurrence of IgG anti-Sarcocystis (7/32; $21.88 \%)$ and anti-T. gondii $(11 / 32 ; 34.38 \%)$ antibodies. The evaluating of animals raised on pasture, semi-extensively and extensively, showed a higher percentage of seropositivity for $N$. caninum $(9 / 34 ; 26.47 \%)$. The high occurrence of animals seropositive to the studied protozoa reinforces the importance of controlling and preventing these agents in the region, as they have the potential to cause a high impact on equid farming, mainly involving reproductive losses and equine protozoal myeloencephalitis (EPM).

Key words: Neosporosis. Toxoplasmosis. EPM. Reproductive diseases.

\section{Resumo}

A criação de equinos geralmente está articulada como atividade secundária nas propriedades, nas quais os animais são utilizados para lazer ou trabalho. Dessa forma é importante considerar a sanidade desses animais, buscando entender quais os principais agentes que circulam em determinada propriedade ou região. Com isso, o presente trabalho teve por objetivo avaliar a presença de anticorpos IgG anti-Sarcocystis spp., anti-Toxoplasma gondii e anti-Neospora spp. em equinos na região Oeste de Santa Catarina. Foram analisadas 100 amostras de soro de equinos de 10 propriedades, localizadas nos municípios de Faxinal dos Guedes, Xaxim e Xanxerê, no período de junho a dezembro de 2019. As amostras foram avaliadas por Reação de Imunofluorescência Indireta (RIFI) para detecção de anticorpos da classe IgG contra os três agentes. Os resultados obtidos demonstram que os equinos da região apresentam soropositividade contra os três agentes estudados, sendo 11\%, para Sarcocystis spp. 21\%, para T. gondii e 20 \%, para Neospora spp. $\mathrm{Na}$ análise da presença destes protozoários em diferentes ambientes, observou-se que tanto equinos estabulados ou criados de forma extensiva ambos apresentaram já terem entrado em contato com os agentes pesquisados. Animais que vivem apenas estabulados, apresentaram maior ocorrência de anticorpos IgG anti - Sarcocystis (7/32; 21,88\%) e anti-T. gondii (34.38\%-11/32). Quando avaliados os animais criados a pasto, de forma semi-extensiva e extensiva, houve um percentual maior de soropositividade para $N$. caninum (26.47\% -9/34). A alta ocorrência de animais soropositivos aos protozoários estudados reforça a importância com o controle e prevenção desses agentes na região, uma vez que estes têm potencial para causar grande impacto na equideocultura, envolvendo principalmente as perdas reprodutivas, além da mieloencefalite protozoária equina (EPM).

Palavras-chave: Neosporose. Toxoplasmose. EPM. Doenças reprodutivas. 


\section{Introduction}

Parasitic diseases stand out among the diseases with an impact on equine health since they can cause sanitary and, consequently, economic losses to animal farming (Molento, 2005). The protozoa Sarcocystis neurona, Toxoplasma gondii, and Neospora spp. are intracellular parasites that belong to the phylum Apicomplexa and can affect different hosts. Infections with these protozoa are described in equines, often underdiagnosed, since most equines are asymptomatic, with no neurological or reproductive changes (Cazarotto et al. 2016). The infections are directly related to the animal raising environments and the presence of the respective definitive hosts on the farms, i.e., opossums for S. neurona, felids for T. gondii, and canids for Neospora spp. (Ribeiro et al. 2016). Infection with these protozoa in equines occurs mainly horizontally, when definitive domestic or wild hosts are present in locations close to the equine's facilities, favoring infection after ingestion of sporulated oocysts or sporocysts present in pastures, food, and water (Shapiro et al., 2019). Transmission can be facilitated by the wandering characteristic of canids and felids, which have greater access to the carcasses of infected animals, favoring later horizontal transmission to equines (Villalobos et al., 2012).

The protozoan S. neurona is responsible for equine protozoal myeloencephalitis (EPM), characterized by the development of locomotor abnormalities of the hindlimbs, leading to muscle atrophy and, in some cases, paralysis of the cranial nerves. Equines are accidental hosts and become infected after ingesting the sporozoites present in food and water contaminated with opossum feces (Dubey et al., 2015; Ribeiro et al., 2016). The time of the year can be one of the main risk factors for the ingestion of sporocysts, as the reproductive season of opossums occurs during the spring, when these animals become more active, thus enabling the dissemination of the evolutional form of the protozoan in the environment. Moreover, this season shows the most favorable climate conditions for the parasite survival in the environment. Lucio et al. (2020) detected, through PCR and sequencing, S. neurona in muscle tissues of naturally infected domestic cats, and these animals can be part of the cycle as intermediate hosts for this species. The worldwide seroprevalence of S. neurona ranges from $0 \%$ to $89.2 \%$ (Dubey et al., 2015). In Brazil, there are reports in the states of Minas Gerais (26\%) (Ribeiro et al., 2016), Roraima (42\%) (Spohr et al., 2018), and Santa Catarina, where Cazarotto et al. (2016) found $41.37 \%$ of seropositive animals. Neurological clinical conditions in equines can also be associated eventually with infections by the protozoa T. gondii and Neospora spp. (James, Smith, Packham, Conrad, \& Pusterla, 2017).

Toxoplasmosis, caused by the agent $T$. gondii, is considered one of the most important zoonoses worldwide due to the diversity of intermediate hosts that may be involved. In addition to humans, several other animals, including equids, are intermediate hosts for this parasite. Infection with this protozoan can have consequences, ranging from reproductive, neurological, or ocular disorders in equines (James et al., 2017). The risk of infection for intermediate hosts is not necessarily related to the presence of the definitive host (felids) on the farm due to the possibility of spreading oocysts in the environment through wind, rain, arthropods, and earthworms. Moreover, oocysts have ample resistance in 
the environment after sporulation, remaining infectious for up to 18 months, being essential for horizontal infection (Shapiro et al., 2019). The worldwide seroprevalence of $T$. gondii in equines ranges from $0 \%$ to $72.2 \%$ (Meng, Li, Yao, Cong \& Shan, 2018). Studies carried out in Brazil have demonstrated variation of seropositive animals in different regions, with values of $12.5 \%$ in the Northeast region (Guerra et al., 2018), 7.8\% in Paraíba (Oliveira et al., 2012), and $14.4 \%$ in Alagoas (Valença et al., 2015); 17.0\% in Paraná (Finger et al., 2013) and $32.1 \%$ in Santa Catarina (South region) (Cazarotto et al., 2016); 19.9\% in Minas Gerais (Southwest region) (Ribeiro et al., 2016); and $18.5 \%$ in Roraima (North region) (Spohr et al., 2018).

Neosporosis, a disease caused by the protozoan $N$. caninum, has a great economic impact on cattle due to its reproductive losses and neonatal diseases. In equines, studies have shown the association of the infection of $N$. caninum and $N$. hughesi with the occurrence of abortions and neonatal diseases and neurological problems, respectively (James et al., 2017). The risk of equine infection due to contamination of environments and food is entirely related to the way the definitive host (canids) has access to the place where equines live. The contamination of the environment occurs through the elimination of oocysts in the feces of infected canids, which favors the horizontal transmission of the disease through the ingestion of food and water contaminated by the protozoan oocysts. The protozoan affects cattle and equines and the worldwide prevalence in the latter species varies between 0\% to 35\% (Dubey, Venturini, Venturini, McKinney, \& Pecoraro, 1999), and studies carried out in Brazil show a variation of $14.4 \%$ to $48.27 \%$ (Spohr et al., 2018).

Given the importance of these protozoa in equine health and the lack of information, especially in the region of this research, the present study aimed to evaluate the occurrence of IgG anti-Sarcocystis spp., anti-T. gondii, and anti-Neospora spp. antibodies in equines in western Santa Catarina, Brazil.

\section{Material and Methods}

The research was carried out with 100 animals in 10 farms, two in the municipality of Faxinal dos Guedes, three in Xaxim, and five in Xanxerê, all located in the western region of the State of Santa Catarina, Brazil (Figure 1), from June to December 2019. The animals were sampled randomly with collections at different environments, that is, 33 animals were raised in the field, 34 were closed and in contact with the external environment during certain periods, and the other 33 animals were stabled. Animals on the same farm could be raised on different systems. This study was approved by the ethics committee on the use of animals (CEUA), under protocol number 76/2018 of the Western University of Santa Catarina - UNOESC. 


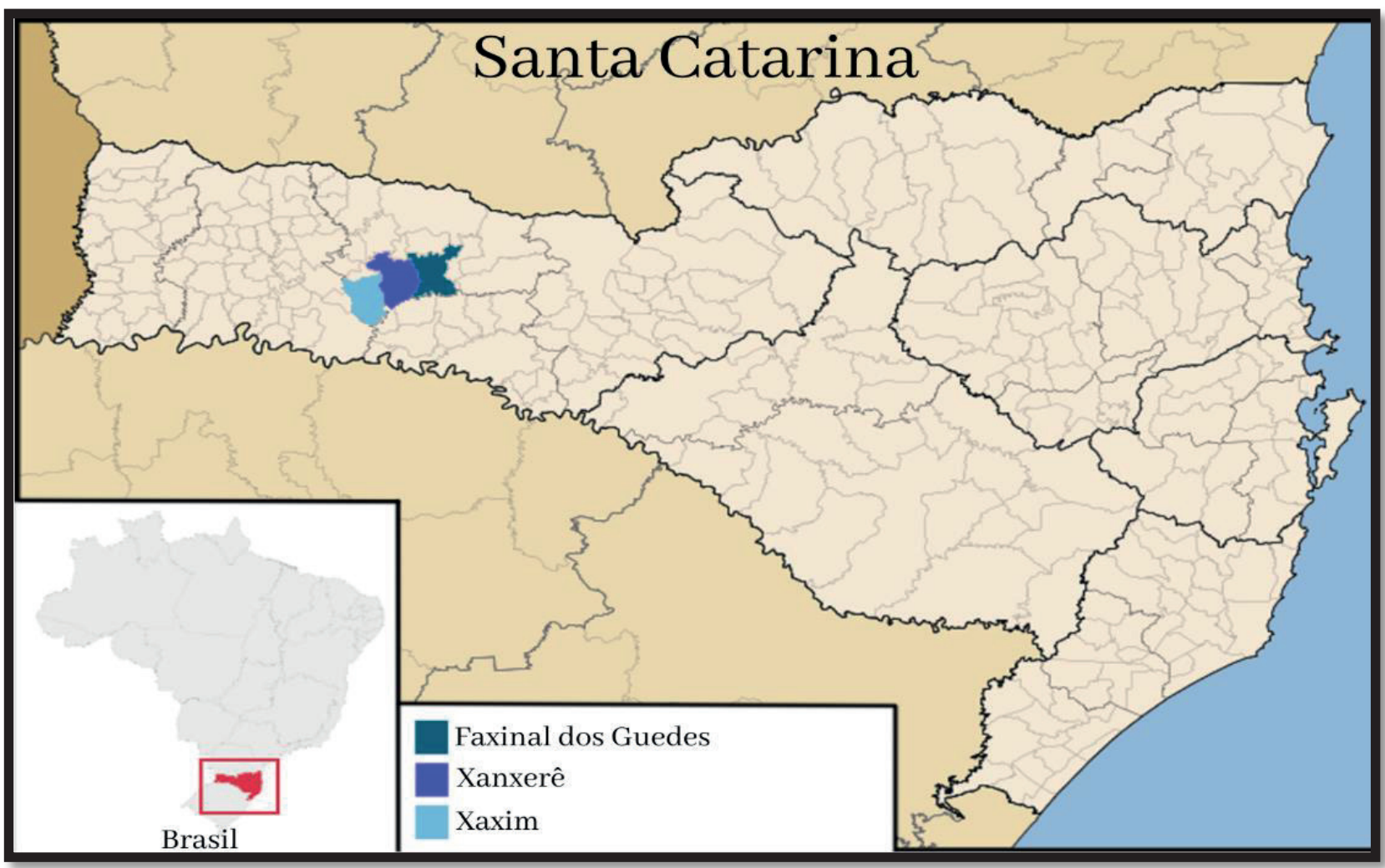

Figure 1. Map of the State of Santa Catarina with the cities where the samples were collected to verify the occurrence of IgG anti-Neospora spp., anti-Toxoplasma gondii, and anti-Sarcocystis spp. antibodies in equines from different raising systems.

Approximately $5 \mathrm{~mL}$ of blood samples were collected directly from the jugular vein using a vacutainer collector and stored in test tubes without anticoagulant. After collection, the samples were sent to the laboratory of veterinary parasitology, where each sample was centrifuged to obtain the serum and then stored in microtubes at a temperature of -20 ${ }^{\circ} \mathrm{C}$ until processing the analyses. Additionally, information such as the presence of opossum, dog, or cat was obtained on the farms.

The antibody research was carried out using samples subjected to an indirect immunofluorescence reaction (IIFR), using Sarcocystis spp. merozoites as antigens, obtained from isolates through direct examination of the bovine heart naturally infected. Tachyzoites of the $\mathrm{RH}$ strain from inoculum taken from mice and tachyzoites of the NC1 strain maintained in cell culture were used for the research with $T$. gondii and $N$. caninum, respectively. The serum samples were subjected to dilutions of 1:50 (Sarcocystis spp.), 1:64 (T. gondii), and 1:50 ( $N$. caninum). The commercial conjugate anti-equine IgG, produced in rabbits (Sigma-Aldrich ${ }^{\circledR}$, USA), was used as a secondary antibody for all reactions at dilutions of 1:500. Serum samples known to be positive and negative for the presence of antibodies against the three agents were used as positive and negative controls, respectively, 
in each slide. Samples with a titration of 50 for Sarcocystis spp. (Antonello et al., 2016), 64 for T. gondii, and 50 for Neospora spp. (Cazarotto et al., 2016) were considered positive. The slides were read using an Optiphase INV403 epi-fluorescence microscope at a 400X magnification, considering positive the samples with fluorescence at the edge of merozoites or tachyzoites. The data were tabulated and analyzed using frequency analysis.

\section{Results and Discussion}

The results demonstrated that equines from the west of Santa Catarina have antibodies to the different studied protozoa. The 100 samples showed that $40 \%$ of the animals were seropositive. Among them, 31\% were seropositive for only one of the three agents surveyed and $9 \%$ of the animals were positive for more than one agent, with $4 \%$ being positive for T. gondii and Sarcocystis spp., $3 \%$ for the three agents (Neospora spp., T. gondii, and Sarcocystis spp.), and only 2\% for Neospora spp. and T. gondii. Most results corroborate with other studies, except concerning seropositivity for Neospora spp. and Sarcocystis spp. simultaneously, which was not found in the present study but described in $2.8 \%$ of cases by Ribeiro et al. (2016) and $16.5 \%$ of cases by Spohr et al. (2018).

Regarding the occurrence of Sarcocystis spp., $11 \%(11 / 100)$ of the animals were seropositive. Some authors reported a higher occurrence of seropositive animals than that found in this study, such as $26 \%$ in the state of Minas Gerais (Ribeiro et al., 2016), $41.37 \%$ in Santa Catarina (Cazarotto et al., 2016), and $42.2 \%$ in Roraima (Spohr et al., 2018). In the present study, $46 \%$ of the owners reported that opossums were present in the vicinity of the stables and pastures where the animals stayed, mainly farms close to forests. The presence of this host is a potent risk factor for environmental contamination due to sporocysts, which remain viable for a long period and are capable of contaminating water and food. The distribution of opossums of the genus Didelphis occurs throughout the American continent in diverse environments, from wetlands and forests to bush pastures. However, deforestation and the consequent imbalance of their habitat have led to their displacement to areas where there is domestic housing, such as farms and studs, in search of food, thus contaminating the equine food, becoming accidental hosts after sporocysts ingestion (Dubey et al., 2015).

The percentage of animals seropositive for T. gondii observed in the present study was $21 \%(21 / 100)$. This result is in line with other studies carried out in Brazil, which varied from 7.8 and 22.8\% (Oliveira et al., 2012; Finger et al., 2013; Valença et al., 2015; Ribeiro et al., 2016; Guerra et al., 2018; Spohr et al., 2018), including Santa Catarina (Cazarotto et al., 2016). In the farms under study, $69 \%$ of the equines had contact with felids in close environments. According to the literature, the proximity of equines with domestic and wild animals increases the risks of environmental contamination and their consequent infection. Another important factor that facilitates transmission to equines and other hosts is the quantity and viability of oocysts excreted by domestic and wild felids, which can excrete millions of oocysts, contaminating pastures and food through the wind, water, and insects, for example, being viable in the soil for months, depending on humidity and temperature (Dubey et al., 1999). 
The occurrence of anti-Neospora spp. antibodies in the present study reached $20 \%$ (20/100). Studies carried out in Brazil have shown a variation of $14.4 \%$ to $48.27 \%$ (Cazarotto etal., 2016; Spohr etal., 2018). These variations in the percentage of antibodies for these protozoa may be variants of the different diagnostic techniques, besides differences in raising and management these animals (Spohr et al., 2018). Among the farms under study, 74\% of the animals had contact with dogs. Although it does not have a statistical relationship, it is noteworthy that the potential risk of horizontal contamination is higher, considering the presence of infected intermediate hosts and, consequently, canids capable of ingesting tissues and contaminating environments with oocysts (Villalobos et al., 2012). Moreover vertical transmission can also be considered important although its effectiveness is reduced in equines due to the placental peculiarities of this species (Ribeiro et al., 2016).

The evaluated equines were housed in different environments and antibodies can be observed in animals under different conditions. Animals that lived in exclusively closed systems, intensively, showed a higher occurrence of anti-Sarcocystis spp. (7/32 $21.88 \%)$ and anti-T. gondii antibodies (11/32; $34.38 \%)$. The animals raised on pasture, semi-extensively and extensively, showed a higher percentage of seropositivity for N. caninum (9/34, 26.47\%). Although no statistical difference was observed, these data are important because there is a possible relationship between the highest incidence of the intensive system and a higher occurrence of seropositive animals. This factor can be related to the proximity of equines with dogs, cats, and opossums, considered definitive hosts of the studied agents. It favors horizontal transmission through sporocysts (Sarcocystis spp.) and oocysts (T. gondii and Neospora spp.). Meng et al. (2018) observed that animals grazing in backyards, closer to the definitive hosts, showed higher seroprevalence than those that lived in fields. Thus, the proximity of domestic and wild animals to the various sources of infection (pasture, hay, and water) also contributes to the transmission of these protozoa, except when the animals receive individualized food in the stalls, without contact with pastures, which reduces the chances of contamination (Dubey et al., 2015; Ribeiro et al., 2016).

Although most of the farms submitted to sampling presented sanitary management considered efficient, with veterinary assistance and sanitary protocols, many of these animals had contact with definitive hosts. Also, according to Guerra et al. (2018), the higher occurrence in stabled animals may be associated with the fact that most equines are used for sporting purposes, thus having higher contact with several different environments, in addition to the proximity of definitive hosts with the food.

\section{Conclusion}

The percentage of animals seropositive to the three agents presented and discussed in this study proves the high prevalence, regardless of the environment in which the animals are raised. The presence of these protozoa in the studied region reinforces the importance of prophylaxis and control measures through permanent education. These measures are essential to reduce the prevalence of these protozoa in equine raising, given the economic losses resulting from infections, such as reproductive losses, besides equine protozoal myeloencephalitis. 


\section{Acknowledgments}

To the government of the State of Santa Catarina for granting a Research Scholarship via the Santa Catarina University Scholarship Program - UNIEDU (Art. 170).

\section{References}

Antonello, A. M., Cadore, G. C., Pivoto, F. L., Camillo, G., Braunig, P., Sangioni, L. A., Vogel, F. S. F. (2016). Intra-uterine exposure of horses to Sarcocystis spp. Antigens. Arquivo Brasileiro de Medicina Veterinária e Zootecnia, 68(2), 271-275. doi: 10.1590/1678-4162-8227

Cazarotto, C. J., Balzan, A., Grosskopf, R. K., Boito, J. P., Portella, L. P., Vogel, F. F., Silva, A. S. da. (2016). Horses seropositive for Toxoplasma gondii, Sarcocystis spp. and Neospora spp. Possible risk facotrs for infection in Brazil. Microbial Pathogenesis, 99, 30-35. doi: 10.1016/j. micpath.2016.07.016

Dubey, J. P., Venturini, M. C., Venturini, L., McKinney, J., \& Pecoraro, M. (1999). Prevalence of antibodies to Sarcocystis neurona, Toxoplasma gondii and Neospora caninum in horses of Argentina. Veterinary Parasitology, 86(1), 59-62. doi: 10.1016/ S0304-4017(99)00127

Dubey, J. P., Howe, D. B., Furr, M., Saville, W. J., Marsh, A. E., Reed, S. M., \& Grigg, M. E. (2015). An update on Sarcocystis neurona infections in animals and equine protozoal myeloencephalitis (EPM). Veterinary Parasitology, 209(1/2), 1-42. doi: 10.1016/j. vetpar.2015.01.026
Finger, M. A., Villalobos, E. M. C., Lara, M. H., Cunha, E. S., Barros, I. R., Fo., Dornbusch, P. T., Biondo, A.W. (2013). Detection of anti-Toxoplasma gondii antibodies in cart horses in the metropolitan region of Curitiba, Paraná, Brasil. Revista Brasileira de Parasitologia Veterinária, 22(1), 179-181. doi: 10.1590/s1984-2961201300500001

Guerra, N. R., Almeida, J. C., Silva, E. L., Silva, E. M., Santos, J. A. M., Lepold, R., Alves, L. C. (2018). Soroprevalência de Toxoplasma gondii em equídeos do Nordeste do Brasil. Pesquisa Veterinária Brasileira, 38(3), 400406. doi: 10.1590/1678-5150-pvb-5143

James, K. E., Smith, W. A., Packham, A. E., Conrad, P. A., \& Pusterla, N. (2017). Toxoplasma gondii seroprevalence and association with equine protozoal myeloencephalitis: a case-control study of Californian horses. The Veterinary Journal, 224, 38-43. doi: 10.1016/j.tvjl.2017.05.

Lucio, B. M., Minuzzi, C. E., Avila, N. C. de, Tondo, L. A. S., Vogel, F. S. F., Kommers, G. D., Flores, M. M. (2020). Natural occurring muscular Sarcocystis in urban domestic cats (Felis catus) without Sarcocystisassociated disease. Acta Parasitologica. doi: 10.1007/s11686-020-00262-7

Meng, Q. F., Li, D., Yao, Z., Cong, W., \& Shan, X. F. (2018). Seroprevalence of Toxoplasma gondii infection and variables associated with seropositivity in donkeys in eastern China. Parasite, 25(66). doi: 10.1051/ parasite/2018066

Molento, M. B. (2005). Resistência parasitária em helmintos de equinos e propostas de manejo. Ciência Rural, 35(6), 14691477. doi: 10.1590/S0103-84782005000 600041 
Oliveira, R. B., F., Malta, K. C., Oliveira, J. M. B., Albuquerque, P. P. F., Mota, R. A., Santana, V. L. A., Pinheiro, J. W., Jr. (2012). Epidemiological situation of Toxoplasma gondii infection in equids from Brejo Paraibano microregion. Pesquisa Veterinária Brasileira, 32(10), 995-1000. doi: 10.1590/S0100-736X201200100008

Ribeiro, M. J. M., Rosa, M. H. F., Bruhn, F. R. P., Garcia, A.M., Rocha, C.M.B.M.,\&Guimarães, A. M. (2016). Soroepidemiologia de Sarcocystis neurona, Toxoplasma gondii e Neospora spp. entre cavalos no sul de Minas Gerais, Brasil. Revista Brasileira de Parasitologia Veterinária, 25(2), 142-150. doi: 10. 1590/s1984-29612016029

Shapiro, K., Bahia-Oliveira, L., Dixon, B., Dumètre, A., de Wit, L. A., VanWormer, E., \& Villena, I. (2019). Environmental transmission of Toxoplasma gondii: Oocysts in water, soil and food. Food and Waterborne Parasitology, 12(e00049), 1-18. doi: 10.1016/j.fawpar.2019.e00049
Spohr, K. A. H., Borges, A. M. C. M., Ribeiro, T. M. P., Jayme, V. S., Godoy, I., Nakazato, L., Aguiar, D. M. (2018). Risk factors associated to the prevalence of antiSarcocystis neurona, Neospora spp. and Toxoplasma gondii antibodies in horses from Roraima, Brazilian Amazon. Pesquisa Veterinária Brasileira, 38(7), 1337-1343. doi: 10.1590/1678-5150-pvb-5127

Valença, S. R. F., Valença, R. M. B., Pinheiro Junior, J. W., Alburquerque, P. P. F., Souza, O. L., Neto, \& Mota, R. A. (2015). Risk factors of occurrence of Toxoplasma gondii among horses in the state of Alagoas, Brazil. Acta Parasitologica, 60(4), 707-711. doi: 10.1515/ap-2015-0100

Villalobos, E. M. C., Furman, K. E., Lara, M. C. C. S., Cunha, E. M. S., Finger, M. A., Busch, A. P. B., Biondo, A. W. (2012). Detection of Neospora sp. antibodies in cart horses from urban áreas of Curitiba, Southern Brazil. Revista Brasileira Parasitologia Veterinária, 21(1), 68-70. doi: 10.1590/S19 84-29612012000100014 
